\section{A SYNOPSIS OF FORENSIC MEDICINE AND TOXICOLOGY}

By E. W. Carlyl Thomas, M.D., B.Sc., D.P.H. 3rd Edition. Pp. viii + 180. Bristol: John Wright \& Sons, Ltd. I954. I2s. 6 d.

This new edition shows little change except for modifications due to the National Health Service Act. It remains a useful reference book for practitioners and for students about to take their final examinations.

S.R.

\section{MAMMALIAN GERM CELLS}

A Ciba Foundation Symposium

Edited by G. E. W. Wolstenholme, O.B.E., M.A., M.B., B.Ch. Pp. xvi +302 , with 54 illustrations. London: J. \& A. Churchill Ltd. 1953. 3os.

This book contains the proceedings of a Ciba Foundation symposium concerned with the ' Physiology of Mammalian Germ Cells.' Included are 25 communications, each of which is succeeded by a report of the general discussion that followed.

The book is divided into two sections: Part I dealing with spermatozoa, and Part II with ova. As Dr. Folley points out in his foreword, reproductive science is ...' on the verge of revolutionary applications arising from discoveries in train or shortly to come,' and many of the papers indicate what are likely to be the principal directions of advance in this field. Much of the work reported in Part I deals with problems directly or indirectly connected with artificial insemination and includes papers on various aspects of spermatozoan biochemistry and metabolism and on the preservation of sperms at low temperatures. In the second part, there is emphasis on such matters as the culturing of eggs in vitro, the possibility of fertilizing eggs in vitro, and the preservation of living ova at low temperatures.

This is a most interesting and valuable book, and although as Dr. Folley states, most of the technical advances foreshadowed in this book are likely to be applied mainly to stockbreeding, ' the fact must be faced that they can also be applied to man. . . , C.L.F.

\section{ANATOMY FOR SURGEONS}

Vol. I: The Head and Neck

By W. Henry Hollinshead, Ph.D. Pp. xii +56 with 326 illustrations. London: Cassell \& C\&. Ltd. r954. 90 s.

This is the first of three volumes on surgical anatomy: 'The Head and Neck,' 'The Thorax, Abdomen and Pelvis,' and 'The Back and Limb:' The sub-division is intended to give the books ${ }_{a}$ reasonable size and to allow the surgeon to reffor easily to his own specialty. The text has been regd and approved by the heads of the appropriate departments of the Mayo Clinic and Foundatioh, and incorporates much recent anatomical and surp. gical work. This first volume will appeal less to the general surgeon than to the otologist, ophthal mologist and the neurosurgeon, who are indega well served by it.

In his preface Professor Hollinshead explains intention of presenting regional anatomy as it is particular interest to the surgeon " with a minimume of soporific effect ' - an aim unusual in anatomist but altogether praiseworthy. He achieves his erad by clear unambiguous writing, by careful divisio into sections, by the choice of spacious printing and by the excellence of his many diagrams. These are well drawn, straightforward, uncrowded, and with the added benefit of having the name structures printed around the diagram as neer possible, relieving the reader of the strain of referring constantly to letters or numbers be The print is clear, and the whole presentation is attractive as I have ever seen in a book on anatomn

The author, in addition to expounding orthole anatomy, not only discusses all the variable pittions of structures important to the surgeon $\mathrm{but}$ also indicates the relative benefits of the differeat anatomical approaches. There is no intention he of replacing standard textbooks of operative sua gery, but merely the placing of all relevant facts front of the surgeon without superfluous detaf. And this is admirably done. Professor Hollinsheag takes pains to hold the reader's attention, and most surgeons will find here a book that is"a pleasu丝 to consult. Extensive references are unobtrusivedy kept at the end of each section, and the index is complete and clear.

This is an outstanding book on surgical anatom; and when one remembers that anatomy does n $\bar{g} t$ change very rapidly and that this book will be up to date for many years to come, one may we 1 consider its expense amply justified. 